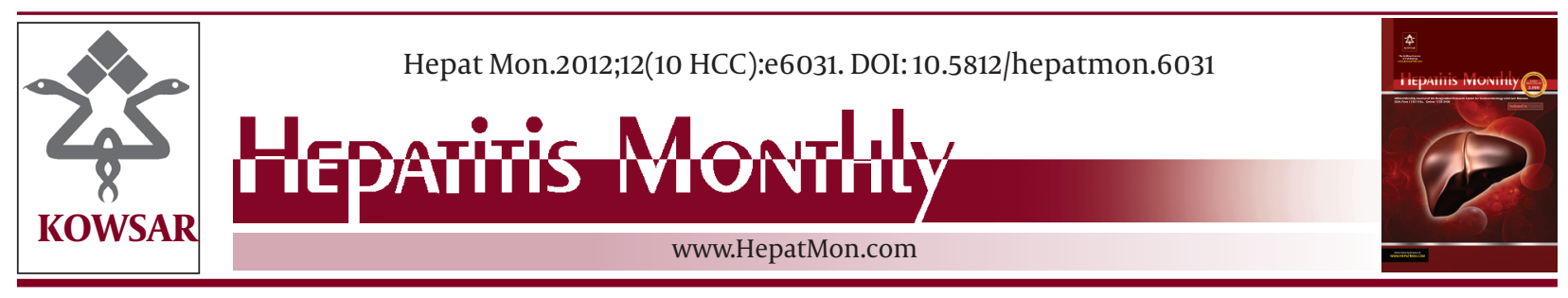

\title{
Effects of Antiviral Therapy on the Recurrence of Hepatocellular Carcinoma After Curative Resection or Liver Transplantation
}

\author{
Yan $\mathrm{Du}^{1}$, Tong Su ${ }^{1}$, Yibo Ding ${ }^{1}$, Guangwen $\mathrm{Cao}{ }^{{ }^{*}}$ \\ ${ }^{1}$ Department of Epidemiology, Shanghai Key Laboratory of Medical Biodefense, Second Military Medical University, Shanghai, China
}

\begin{tabular}{l}
\hline A R T I C L E I N F O \\
\hline Article type: \\
Review Article \\
\hline Article history: \\
Received: 27 Nov 2011 \\
Revised: 09 Jan 2012 \\
Accepted: 02 Feb 2012 \\
\hline
\end{tabular}

\section{Keywords:}

Carcinoma, Hepatocellular

Surgical Procedures, Operative

Recurrence

Survival

\begin{abstract}
A B S T R A C T
Context: Hepatocellular carcinoma (HCC) is a fatal disease. Chronic hepatitis B virus (HBV) and/or hepatitis C virus (HCV) infection is the major cause of HCC. High viral replication rate and related hepatic/systematic inflammation are the major risk factors in HCC recurrence after hepatectomy or liver transplantation.

Evidence Acquisition: Some of the carcinogenesis-related HBV mutations are also associated with poor prognosis for HCC patients. Antiviral therapy is an option for improving HCC prognosis after surgery. In case of HBV-associated HCC, treatment with interferon and nucleos(t)ide analogues (NAs), especially interferon, is effective in improving the prognosis. However, long-term use of NAs increases the possibility of developing drug-resistant viral mutations such as the HBV rtA181T/sW172 mutation, which increases the risk of HCC recurrence.

Results: In cases of HCV-associated HCC, standard interferon with or without ribavirin therapy is effective in improving the prognosis of HCV-associated HCC; however, some HCV mutations, such as the amino acid substitution M91L, are associated with treatment failure and a poor prognosis. Therapeutic efficacy needs to be confirmed using largescale, randomized, placebo-controlled clinical trials.

Conclusions: Surveillance of viral mutations during antiviral treatment and a better understanding of the associations of HCC recurrence with viral load, inflammation-associated signaling, and environmental factors can aid the development of more effective strategies for the prevention of HCC recurrence after surgery.
\end{abstract}

Copyright $\odot 2012$ Kowsar Corp. All rights reserved.

- Implication for health policy/practice/research/medical education:

The recurrence rate of hepatocellular carcinoma (HCC) after curative treatment is high and the survival is poor. This review focuses on effects of antiviral therapy on HCC recurrence. It should be important in determining suitable antiviral therapy regimens for the prevention of postoperative HCC recurrence in clinical practice.

Please cite this paper as:

Du Y, Su T, Ding Y, Cao G. Effects of Antiviral Therapy on the Recurrence of Hepatocellular Carcinoma After Curative Resection or Liver Transplantation. Hepat Mon. 2012; 12(10 HCC): e6031. DOI: 10.5812/hepatmon.6031

\section{Context}

Hepatocellular carcinoma (HCC) is the sixth most common malignancy and the third leading cause of cancer death worldwide (1). Chronic infection with hepatitis B virus (HBV) and hepatitis C virus (HCV) accounts for about

\footnotetext{
* Corresponding author: Guangwen Cao, Department of Epidemiology, Second Military Medical University, 800 Xiangyin Rd., Shanghai 200433, China. Tel:+86-2181871060, Fax:+86-2181871060,E-mail:gcao@smmu.edu.cn DOI: $10.5812 /$ hepatmon.6031 Copyright @2012 Kowsar Corp. All rights reserved.
}

$75-80 \%$ of HCC cases worldwide (2). In Asia and Africa, where HCC is endemic, chronic HBV infection is the predominant risk factor, while in the western countries, HCV infection is one of the major risk factors. HCC is a fatal disease. Currently, orthotopic liver transplantation (OLT) and surgical resection are the only curative treatments. OLT has excellent outcomes in patients meeting the Milan criteria (single nodule of $\leq 5 \mathrm{~cm}$ or 2 or 3 nodules of $\leq 3 \mathrm{~cm}$ ), with a 5 -year survival rate of $70 \%$. Nevertheless, because of the strict selection criteria and high costs associated with the therapy, it can be offered to only a small 
fraction of the affected patients (3). Therefore, surgical resection is the main curative treatment for noncirrhosis patients and cirrhosis patients with well-preserved liver function. However, it is reported that up to $70 \%$ of the patients show relapse within 5 years after curative resection (4). The high rate of recurrence is a major obstacle to improving prognosis. Early recurrence (within 2 years) is mainly related to metastasis and dissemination of primary HCC, whereas late recurrence (after $\geq 2$ years) mostly results from de novo tumors arising because of the "field effect" in the diseased liver and is closely associated with high viral loads and hepatic inflammatory activity $(5,6)$. Therefore, antiviral and anti-inflammatory therapies before and after curative treatment may be crucial in preventing HCC recurrence and in improving survival. Current approved medications for chronic hepatitis $B$ $(\mathrm{CHB})$ treatment are interferon- $\alpha$ (IFN $\alpha$ ) and nucleos $(\mathrm{t})$ ide analogues (NAs), including lamivudine (LAM), entecavir (ETV), tenofovir disoproxil fumarate (TDF), adefovir dipivoxil (ADV), and telbivudine (TBV) (7). Conventional treatment with IFNa and the pegylated, long-acting formulation (PEG-IFNa) in combination with the guanosine analog ribavirin (RBV), are considered a standard modality for chronic hepatitis $C$ treatment (8). There are no anti-inflammatory drugs available for the prevention of HCC recurrence after surgery, but antiviral treatment and antioxidants can decrease liver inflammation (9). In this review article, we have re-evaluated the reported effects of antiviral treatments on the occurrence of HCC after surgical treatment, and we have pointed out existing problems in current studies.

\section{Evidence Acquisition}

2.1. Why do HCC Patients Need Postoperative Antiviral Treatment and What are the Characteristics of These Patients?

High viral loads in the serum or liver and hepatitis B e antigen (HBeAg) seropositivity indicate a high viral replication rate. The presence of HBeAg either before or after curative treatment for HCC is significantly associated with early recurrence and poor survival (10-12). Serum hepatitis B core-related antigen (HBcrAg), consisting of HBeAg, hepatitis B core antigen, and a 22-kDa precore protein coded with HBV precore/core gene, could be a surrogate marker for the intrahepatic covalently closed circular DNA (cccDNA) pool. A high serum level of HBcrAg is an independent factor in HCC recurrence (13). The severity of hepatic inflammation, which is well correlated with viral serostatus, may also be a factor that affects intrahepatic recurrence, which is more likely to originate from metachronous carcinogenesis (14). High levels of HBV DNA in peritumoral liver tissues of HCC patients independently predicted poor disease free survival (DFS) and overall survival (OS) after surgical resection (15). Sustained low hepatitis $B$ viral load $\left(<10^{4}\right.$ copies $\left./ \mathrm{mL}\right)$ is significantly associ- ated with improved long-term recurrence-free survival and OS (16). In addition, HBV viral load is one of the main prognostic factors for local recurrence after complete radiofrequency ablation (RFA) of small HBV-related HCC (12). Thus far, there is not much information on the association between HCV RNA concentration and HCC recurrence after surgery. The available data has shown that HCV concentration is an independent prognostic factor for OS and recurrence $(17,18)$. These data indicate that high rates of viral replication are positively associated with a high risk of HCC recurrence after surgery. Chronic inflammation supported by chronic HBV or HCV infection orchestrates a tumor-friendly microenvironment that is essential for carcinogenesis and metastasis. Chronic inflammation and high viral replication rate are important predictors of adverse outcome after HCC curative treatments. Chronic inflammation plays a crucial role in cancer initiation and promotion. Abnormal inflammation, including aberrant production of pro-inflammatory mediators and increased expression of oncogenes, matrix metalloproteinases, and pro-inflammatory transcription factors such as nuclear factor kappa-light-chain-enhancer of activated B cells (NF- $\mathrm{B})$, signal transducers and activators of transcription 3 (STAT3), activating protein-1 (AP-1), and hypoxia-induced factor- $1 \alpha$ (HIF-1 $\alpha$ ) can activate genes mediating tumor cell proliferation, survival, invasion, and angiogenesis (19). High viral replication rates are closely related to hepatic inflammation. Many studies have provided evidence that inflammation-related host factors can predict HCC recurrence and survival after surgical resection or liver transplantation (20-22). All these data support the finding that persistent viral infection-associated inflammation plays an active role in the recurrence of HCC. Inflammation contributes to the formation of HBV mutations and the mutants can in turn facilitate HCC occurrence and progression. One of the common mechanisms of HBV mutagenesis to escape immune clearance is the reduction of $\mathrm{CD}^{+} \mathrm{T}$ cell epitopes. Some of the HBV mutations selected by a compromised immune system during HBV hepatocarcinogenesis are significantly associated with an increased risk of HCC(2325). C1653T, T1753V, A1762T/G1764A, T1674C/G, C1766T/ T1768A, T53C, preS2 start codon mutation, preS1 deletion, C2964A, A2962G, C3116T, C7A, and their combinations are HBV mutations that are significantly associated with an increased risk of HCC occurrence (25-27). PreS deletion is the most common mutation in the pres region. The pres mutations may be generated during the progression of $\mathrm{CHB}$, particularly in IFN-treated patients (28). The preS deletion also affects viral replication by decreasing the expression of surface proteins, which leads to intracellular accumulation of HBV envelope proteins and viral particles, formation of ground-glass hepatocytes, endoplasmic reticulum stress, and oxidative DNA damage (29). All these changes eventually result in hepatocarcinogenesis. In peritumoral tissues, a preS deletion at nt.107-141 and 
preS2 mutations are independently associated with poor DFS and OS after surgery $(23,30)$. A1762T/G1764A in liver tissue can independently predict postoperative survival (15). HCV is hypervariable in a region coding for envelope proteins and escapes immune surveillance. It has been reported that 2 amino acid substitutions in the core region of HCV-1b, Q70R and M91L, are significantly associated with resistance to the standard IFNa plus RBV therapy and an increased risk of HCC (31). Moreover, M91L is significantly associated with recurrence and poor survival in HCC patients after surgery (32). Currently, there are no data showing that the viruses with HCC- or HCC prognosis-associated mutations are still sensitive to IFN and/or NA treatments. We, therefore, suggest that HCC patients who need postoperative antiviral treatments are those who (1) have a high HBV DNA level $\left(>10^{4}\right.$ copies $\left./ \mathrm{ml}\right)$ at the time of surgery (2); are seropositive for HBeAg or have a high serum level of HBcrAg (3); are infected with HBV with the HCC-or HCC prognosis-associated mutations (4); have recurrent HCV after OLT/hepatectomy or HCV with HCC prognosis-associated mutations (5); have high Ishak hepatic inflammation score $(>6)$ or abnormal alanine aminotransferase (ALT); and (6) have over-expression of inflammation-related molecules in HCC specimens or peritumoral liver tissues. Furthermore, since HCC curative resection may reactivate HBV replication (33), HCC patients with a high level of HBV reactivation within 3 months after surgery should also be considered for antiviral treatment.

\subsection{Antiviral Treatment Improves HCC Prognosis 2.2.1 Effects of IFN on HBV- or HCV-Related HCC Survival and Recurrence}

A meta-analysis conducted by Breitenstein et al. (34) pooled data from 7 randomized clinical trials (RCTs) (35-41) between January 1998 and October 2007 and concluded that IFNa had a significant beneficial effect on both survival and tumor recurrence. Two additional meta-analyses published in $2010(42,43)$, including RCTs and non-randomized controlled trails (NRCTs), reported similar results (44-51). Other recent studies have also supported the role of IFN treatment in preventing early recurrence and improving survival after curative treatment of HCC (52-54). However, these studies do not separate HBV-related HCC from HCV-related HCC. Since HBV and HCV have distinctive characteristics and therefore different regimens (i.e., IFN/NAs for HBV-related HCC vs. IFN/RBV for HCV-related HCC) after curative surgery, we summarized the results of HBV-related HCC RCTs and NRCTs in Table 1. For HCV patients, IFNa and PEG-IFN can achieve sustained virologic response (SVR), seronegative for HCV RNA throughout the 6-month post-treatment follow-up period. The patients who achieve SVR following treatment with IFN and RBV usually have a good prognosis; however, in those who do not respond to initial anti- viral therapy, maintaining IFN therapy may not decrease HCC recurrence. These results are summarized in Table 2. HCC recurrence rates and related deaths were significantly lower in patients who received post-OLT IFN therapy for recurrent $\mathrm{HCV}$ (58). Since high viral load is frequently associated with late recurrence of HCC after surgery, antiviral treatment should be solely effective for the prevention of late recurrence. However, it can also efficiently prevent early recurrence of HCC after surgery (52-54). IFN is effective in preventing both early and late recurrence of HCC, possibly due to its effects on angiogenesis, Wnt $/ \beta$ catenin pathways, and immune modulation. Vascular invasion (microscopic vascular invasion or macroscopic venous invasion) is associated with early HCC recurrence (6). IFN $\alpha$ inhibits metastasis and early recurrence of human HCC after curative resection, which is possibly mediated by anti-angiogenesis through down-regulation of expression of vascular endothelial growth factor (VEGF) (55-57). The expression of HBx in hepatocytes activates Wnt/ $\beta$-catenin signaling, and Wnt pathway activation induced by $\beta$-catenin mutations is associated with a poor prognosis $(22,58,59)$. PEG-IFN targets Wnt signaling by inducing nuclear export of $\beta$-catenin, and thus affects the recurrence of HCC (60). It is believed that the principal mechanisms of IFN in prevention of HCC recurrence in patients with viral hepatitis are the suppression of $\mathrm{HBV}$ and HCV replication, inhibition of inflammatory signaling, and tumoricidal effect $(55,57)$. IFN treatment has adverse effects, including flu-like symptoms, fatigue, neutropenia, thrombocytopenia, depression, bone marrow suppression, and unmasking or exacerbation of autoimmune illnesses. These are generally tolerable but may require dose modification and premature withdrawal from the treatment. In addition, antibodies to recombinant IFN, which might be generated during long-term treatment, may limit its biological effects.

\subsubsection{Effects of NAs on HCC Survival and Recurrence}

HBV-positive patients require both sufficient antiviral therapy with NAs and hepatitis B immune globulins (HBIG) after successful liver transplantation to effectively prevent recurrence (61). The introduction of HBIG treatment greatly reduces HBV recurrence after HBV-related OLT. Even thought there is no current consensus on the optimal HBIG dosage and duration, it is widely agreed that HBIG plasma titers should be maintained at a level of least $100 \mathrm{IU} / \mathrm{L}$ during long-term therapy (62). The aims of NA treatment are to inhibit HBV DNA replication, normalize ALT levels, and maintain liver function. NAs target HBV DNA polymerase. Short-term treatment with NAs ( $<6$ months) can prevent post OLT HBV recurrence (63). Since HBcrAg is a predictor of post-treatment recurrence of HCC, suppression of serum HBcrAg and cccDNA by NAs may be important to prevent HCC recurrence (13). LAM is the first NA to treat CHB. It can inhibit viral replication, 
improve liver function, and induce histological improvement of fibrosis (64). However, it has shortcomings, including development of drug resistant strains and attenuation of HBV suppression and other serious clinical challenges (65). The current standard of therapy is either TDF or ETV. In patients mono-infected with HBV, TDF seems to have a low drug resistance rate and good tolerability, as well as few clinically significant side effects. ETV has been found to be a superior antiviral agent with a high genetic barrier. Therapy with ETV is more likely to induce a significant decline in viral loads in both HBeAg-positive and -negative treatment-naïve patients (7). Notably, treatment with NAs does not reduce early recurrence, but it promotes postoperative viral clearance and improves liver function. Several studies have compared the prognosis of HCC patients with and without NA treatments (66-71). Although most of the studies had small sample sizes and relatively short follow-up times, in general the NA treatments exhibited a potential beneficial effect in preventing HCC recurrence and improving survival after curative treatments (Table 3). Long-term usage of NAs is required to effectively inhibit HBV and maintain a low HBV load; however, this strategy leads to a major challenge in HCC management-drug resistance.

\subsubsection{Drug-resistant Viral Mutations Limit NA Therapeu- tic Effect and May Also Promote Hepatocarcinogenesis \\ Long-term use of NAs may generate drug-resistant viral mutations. The most frequently used antiviral therapy for}

\begin{tabular}{|c|c|c|c|c|}
\hline & Patients & Therapy & Survival (OS, DFS, RFS) & Recurrence \\
\hline \multicolumn{5}{|c|}{ RCT } \\
\hline Lin, et al. (2004) (38) & $\begin{array}{l}30 \text { patients after } \\
\text { non-surgical treat- } \\
\text { ment (transarterial } \\
\text { chemoembolization } \\
\text { or percutaneous ace- } \\
\text { tic acid injection) of } \\
\text { HCV- or HBV - related } \\
\text { HCC nodules }\end{array}$ & $\begin{array}{l}\text { IFN- } \alpha \text { intramuscular } \\
\text { injection. Treatment } \\
\text { group A: } 3 \text { MIU } \times 3 / \\
\text { week } \times 24 \text { months. } \\
\text { Treatment group B: } \\
3 \text { MIU } \times 10 / \text { month } \\
\times 6 \text { months, then } 3 \\
\text { MIU } \times 10 / 3 \text { month } \times 18 \\
\text { months }\end{array}$ & Not analyzed & $\begin{array}{l}\text { The HCC recurrence rate } \\
\text { among untreated pa- } \\
\text { tients was } 40 \% \text { at } 1 \text { year, } \\
70 \% \text { at two years, and } \\
90 \% \text { at } 4 \text { years and was } \\
\text { higher than the rates } \\
\text { among patients treated } \\
\text { with IFN- } \alpha \text { ( } 25 \% \text { at } 1 \text { year, } \\
30 \% \text { at two years, and } \\
47 \% \text { at four years) }\end{array}$ \\
\hline Sun, et al. (2006) (39) & $\begin{array}{l}236 \text { patients after } \\
\text { curative resection of } \\
\text { HBV-related HCC }\end{array}$ & $\begin{array}{l}\text { IFN- } \alpha \text { intramuscular } \\
\text { injection, } 3 \text { MIU } \times 2 / \\
\text { week } \times 2 \text { weeks, then } \\
5 \text { MIU } \times 3 / \text { week } \times 18 \\
\text { months }\end{array}$ & $\begin{array}{l}\text { Treated } v \text { s. control: Median } \\
\text { OS, } 63.8 / 38.8 \text { months }(P= \\
0.0003) ; \text { Median DFS, 31.2/17.7 } \\
\text { months, } P=0.42\end{array}$ & $\begin{array}{l}\text { IFN- } \alpha \text { treatment } \\
\text { improved the OS, prob- } \\
\text { ably by postponing } \\
\text { recurrence. }\end{array}$ \\
\hline Lo, et al. (2007) (41) & $\begin{array}{l}80 \text { patients after } \\
\text { curative resection of } \\
\text { predominantly HBV } \\
\text {-related HCC }\end{array}$ & $\begin{array}{l}\text { IFN- } \alpha 2 \mathrm{~b} \text { subcutaneous } \\
\text { injection, } 10 \mathrm{MIU} \times 3 / \\
\text { week } \times 16 \text { weeks }\end{array}$ & $\begin{array}{l}\text { Adjusted RR of death for IFN } \\
\text { treatment was } 0.42(95 \% \mathrm{CI} \text { : } \\
0.17-1.05 ; P=0.063)\end{array}$ & $\begin{array}{l}\text { No significant differ- } \\
\text { ence in the overall DFS }\end{array}$ \\
\hline \multicolumn{5}{|c|}{ NRCT } \\
\hline $\begin{array}{l}\text { Someya, et al. (2006) } \\
(48)\end{array}$ & $\begin{array}{l}80 \text { patients with HBV } \\
\text {-positive cirrhosis } \\
\text { and HCC underwent } \\
\text { curative treatment } \\
\text { (surgical resection or } \\
\text { sufficient ablation) } \\
\text { for HCC }\end{array}$ & $\begin{array}{l}\text { Intermittent IFN- } \alpha \\
\text { injections, } 2-3 / \text { week } \times \\
6 \text { months or longer. }\end{array}$ & Not analyzed & $\begin{array}{l}\text { In the subgroup of } \\
\text { abnormal AST, HCC } \\
\text { recurrence rates in the } \\
\text { IFN group were sig- } \\
\text { nificantly lower than } \\
\text { the non-IFN group ( } P= \\
0.0139 \text { ). }\end{array}$ \\
\hline Qu, et al. (2010) (52) & $\begin{array}{l}568 \text { HBV-related HCC } \\
\text { patients underwent } \\
\text { curative resection. } \\
\text { A median observa- } \\
\text { tion period of } 53.3 \\
\text { months }\end{array}$ & $\begin{array}{l}\text { IFN - } \alpha 1 \mathrm{~b} \text { intramuscu- } \\
\text { lar injection, } 3 \mathrm{MIU} \times \\
2 / \text { week } \times 2 \text { weeks, and } \\
\text { then } 5 \mathrm{MIU} \times 3 / \text { week } \times \\
18 \text { months. }\end{array}$ & $\begin{array}{l}\text { Postoperative IFN-a therapy } \\
\text { was an independent factor } \\
\text { for OS. No significant differ- } \\
\text { ence in DFS rates }\end{array}$ & $\begin{array}{l}\text { Postoperative IFN-a } \\
\text { therapy significantly } \\
\text { reduced early recur- } \\
\text { rence. }\end{array}$ \\
\hline Chan, et al. (2011) (53) & $\begin{array}{l}136 \mathrm{HBV} \text {-related HCC } \\
\text { received hepatec- } \\
\text { tomy }\end{array}$ & $\begin{array}{l}\text { Antiviral therapy after } \\
\text { hepatectomy }\end{array}$ & $\begin{array}{l}\text { Antiviral treatment con- } \\
\text { ferred a significant survival } \\
\text { benefit in stages I and II tu- } \\
\text { mors or HCC without major } \\
\text { venous invasion }\end{array}$ & Not analyzed \\
\hline
\end{tabular}

Abbreviations: AST, Aspartate aminotransferase; DFS, Disease free survival; HBV, Hepatitis B virus; HCC, Hepatocellular carcinoma; IFN, Interferon; MIU, Million international units; NRCT, Non-randomized controlled trail; OS, Overall survival; RCT, Randomized clinical trial; RFS, Recurrence free survival. 


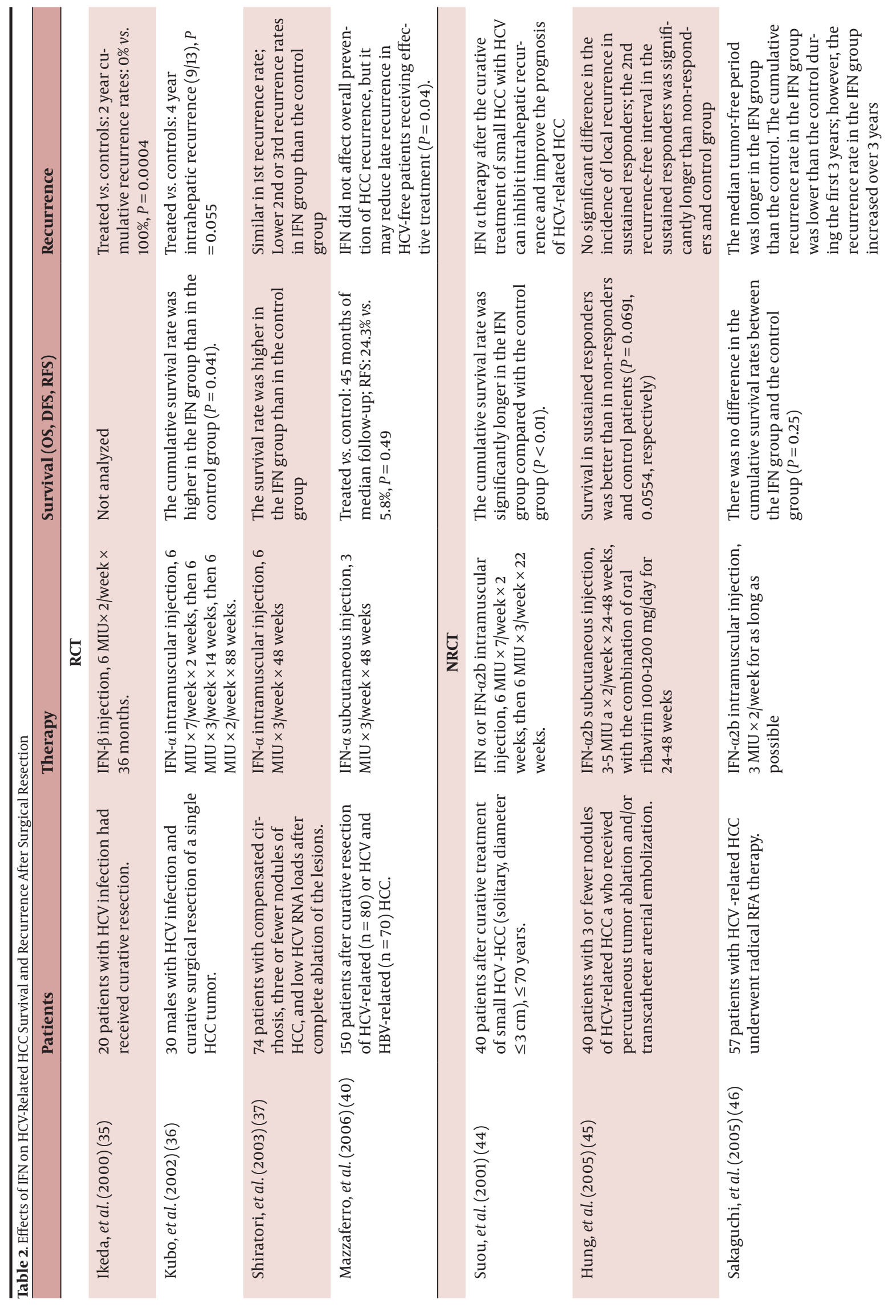




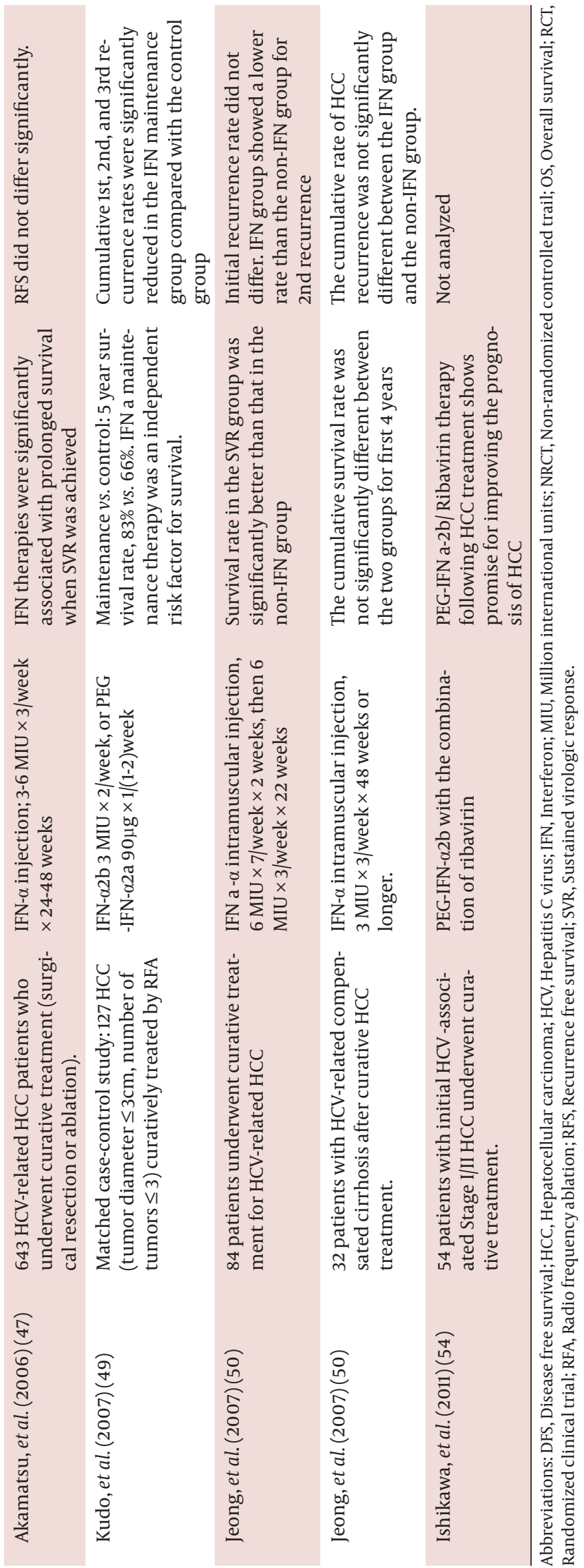

post-transplantation recurrence of HBV infection is LAM, but this drug is associated with a high resistance rate due to tyrosine-methionine-aspartate-aspartate (YMDD) mutants (72). The YMDD mutants may arise under immunosuppression, and emerge after 9-10 months of LAM therapy. The most frequently encountered LAM-resistant mutation at the catalytic YMDD motif is rtM204V/I (73-75, 78-80). The frequency of the mutation increases over the duration of LAM therapy year by year, up to almost 70\% after 5 years (65). In terms of the current standard therapy, resistance to ETV is rare in treatment-naïve patients. However, in the presence of rtM204I/V mutations, ETV resistance arose with the coexistence of rtI169T, rtL180M, rtT184A/F/G/I/L/S, rtS202G/I, or rtM250V mutations $(76,77)$. As for other NAs, the rtN236T mutation is associated with ADV resistance $(76,78)$. The major TBV resistant mutant is rtM204I (79). Another mutant, rtA181T, may arise during prolonged LAM therapy, conferring cross resistance to ADV. Importantly, since the HBV S and polymerase genes overlap with each other, a great proportion of patients with the rtA181T mutation also carry the SW172 nonsense

Figure 1. Major Events in HBV Hepatocarcinogenesis and HBV-Related HCC Prognosis

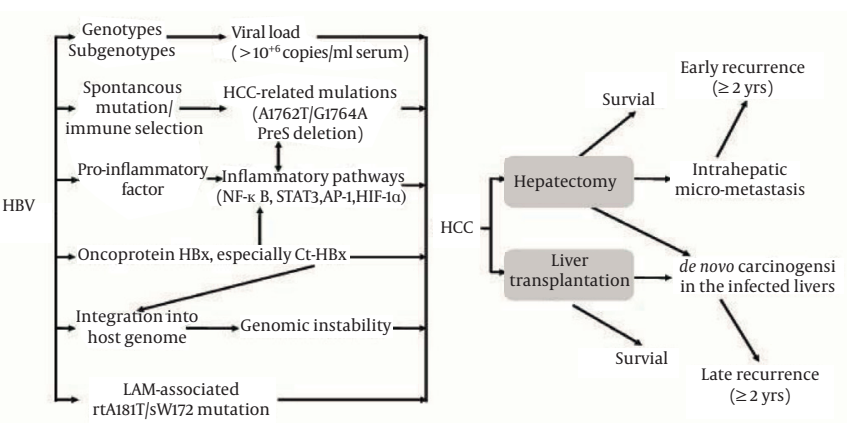

HBIG, Hepatitis B Immune Globulin; HBV, Hepatitis B virus; HCC, Hepatocellular Carcinoma; IFN, Interferon; NA, Nucleos (t)ide Analogue

Figure 2. Major Events in HCV Hepatocarcinogenesis and HCV-Related HCC Prognosis

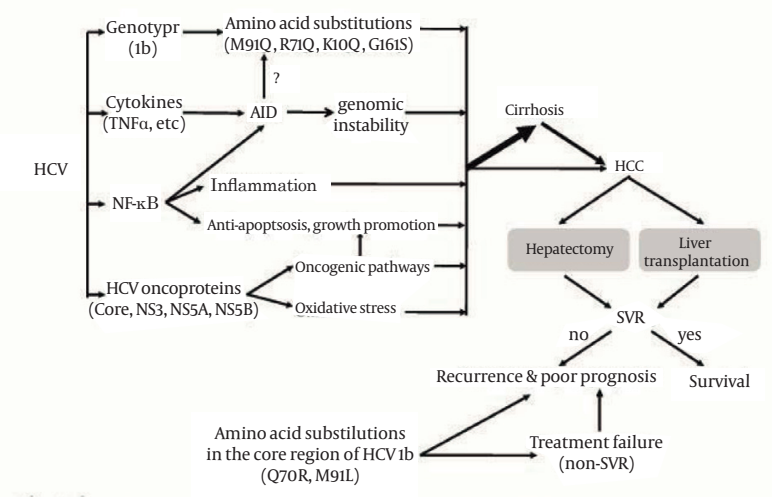

HCC, Hepatocellular Carcinoma; HCV, hepatitis C Virus; SVR, Sustained Virologic Response 


\begin{tabular}{|c|c|c|c|c|}
\hline & Patients & Therapy & Survival (OS, DFS) & Recurrence Rate \\
\hline \multicolumn{5}{|c|}{ Surgical Resection (including RFA) } \\
\hline Piao, et al. (2005) (66) & $\begin{array}{l}70 \text { HCC patients com- } \\
\text { pleted HCC therapy } \\
\text { (local ablation, trans- } \\
\text { arterial chemoembo- } \\
\text { lization, or surgery) }\end{array}$ & $\begin{array}{l}\text { LAM: } 100 \mathrm{mg} / \text { day } \\
\text { orally for more than } \\
24 \text { months }\end{array}$ & $\begin{array}{l}\text { There was no signifi- } \\
\text { cant difference in the } \\
\text { survivals between } \\
\text { the two groups, but } \\
\text { LAM treatment was } \\
\text { associated with low cu- } \\
\text { mulative rate of death } \\
\text { due to liver failure }(P= \\
0.043)\end{array}$ & $\begin{array}{l}\text { No difference was found } \\
\text { between the treatment } \\
\text { group and the control } \\
\text { group (14/30 and } 26 / 40 \text { ) }\end{array}$ \\
\hline Kuzuya, et al. (2007) (67) & $\begin{array}{l}49 \text { HCC patients who } \\
\text { underwent hepatic } \\
\text { resection or RFA for } \\
\text { initial HCC treat- } \\
\text { ment. }\end{array}$ & LAM: $100 \mathrm{mg} /$ day & $\begin{array}{l}\text { The cumulative } \\
\text { survivals of patients in } \\
\text { the treatment group } \\
\text { tended to be higher } \\
\text { than those in the con- } \\
\text { trol }(P=0.063)\end{array}$ & $\begin{array}{l}\text { Cumulative recurrence } \\
\text { rates of HCC did not } \\
\text { significantly differ } \\
\text { between the two groups } \\
(P=0.622)\end{array}$ \\
\hline Kubo, et al. (2007) (68) & $\begin{array}{l}24 \text { patients who had } \\
\text { high serum concen- } \\
\text { trations of HBV DNA }\end{array}$ & LAM: $100 \mathrm{mg} /$ day & $\begin{array}{l}\text { Tumor-free survival } \\
\text { rate was significantly } \\
\text { higher in the treat- } \\
\text { ment than the control } \\
\text { group }(P=0.0086)\end{array}$ & Not analyzed \\
\hline Yoshida, et al. (2008) (69) & $\begin{array}{l}104 \text { HCC patients } \\
\text { underwent RFA treat- } \\
\text { ment. }\end{array}$ & LAM: $100 \mathrm{mg} /$ day & $\begin{array}{l}\text { Overall survival did } \\
\text { not differ between the } \\
\text { two groups }\end{array}$ & $\begin{array}{l}\text { Recurrence-free survival } \\
\text { did not differ between } \\
\text { the two groups }\end{array}$ \\
\hline Li, et al. (2010) (70) & $\begin{array}{l}79 \text { HCC patients } \\
\text { underwent curative } \\
\text { resection, a me- } \\
\text { dian follow-up of } 12 \\
\text { months. }\end{array}$ & $\begin{array}{l}\text { LAM with or without } \\
\text { adefovir dipivoxil }\end{array}$ & $\begin{array}{l}\text { OS was improved for } \\
\text { those patients with } \\
\text { postoperative antiviral } \\
\text { therapy }\end{array}$ & $\begin{array}{l}\text { No significant differ- } \\
\text { ence in recurrence rate } \\
\text { between the treatment } \\
\text { group and the control } \\
\text { group }(76.7 \% \text { and } 91.7 \%)\end{array}$ \\
\hline \multicolumn{5}{|c|}{ Liver Transplantation } \\
\hline $\begin{array}{l}\text { Zimmerman, et al. (2007) } \\
\text { (71) }\end{array}$ & $\begin{array}{l}101 \text { patients under- } \\
\text { went OLT for end- } \\
\text { stage liver disease } \\
\text { secondary to HBV } \\
\text { with concomitant } \\
\text { HCC }\end{array}$ & $\begin{array}{l}\text { LAM: } 150 \mathrm{mg} / \text { day. } \\
\text { HBIG: before } 1998 \text {, } \\
\text { 10,000U, iv, then } \\
\text { 10,000U/d × } 7 \text { days, } \\
\text { then } 10,000 \text { U/month. } \\
\text { After } 1998,10,000 U \text {, } \\
\text { iv, then } 2000 \mathrm{U} / \mathrm{d} \times 6 \\
\text { days, then } 1560 \mathrm{U} \text { im }\end{array}$ & $\begin{array}{l}\text { Patients treated with } \\
\text { combination prophy- } \\
\text { laxis had a significant- } \\
\text { ly lower mortality than } \\
\text { those without }\end{array}$ & $\begin{array}{l}\mathrm{AFP}>500 \mathrm{ng} / \mathrm{mL} \text {, } \\
\text { presence of vascular } \\
\text { invasion, HBV recur- } \\
\text { rence, and combina- } \\
\text { tion prophylaxis were } \\
\text { independent predictors } \\
\text { of HCC RFS }\end{array}$ \\
\hline
\end{tabular}

Abbreviations: DFS, Disease free survival; HCC, Hepatocellular carcinoma; HCV, Hepatitis C virus; IFN, Interferon; MIU, Million international units; NRCT, Non-randomized controlled trail; OS, Overall survival; RCT, Randomized clinical trial; RFA, Radio frequency ablation; RFS, Recurrence free survival; SVR, Sustained virologic response

mutation, resulting in truncation of the pres/S reading frames, which significantly increases the risk of HCC during subsequent courses of NA therapy (80). Drug-resistant viral mutations generated during the long course of NA treatment are becoming one of the major risk factors of poorer HCC prognosis. The important events in HBVor HCV-induced hepatocarcinogenesis and prognosis and the antiviral treatments for the prevention of HCC recurrence after surgical treatment are summarized in Figure 1 and Figure 2, respectively.

\section{Results}

3.1. Regimen of Antiviral Therapy Suitable for the Prevention of HCC Recurrence

So far, there is no consensus on the standard regimen, such as drug combination, dosage, and optimal time of initiation of therapy, to achieve the best prognosis for HCC after curative treatment. The current practice is largely experience-based, and most results, especially for NAs, are from NRCTs. For IFN, previous studies have indicated that there was no difference between intermittent and continuous treatment strategies. The usual dosage is 3-6 million international units (MIU), with some with a 
larger dosage of $10 \mathrm{MIU}$, subcutaneously or intramuscularly. It is usually administrated 2-3 times per week, and needs to last for more than 6 months. It is also a common practice to add RBV to the IFN treatment regimen for HCV-related HCC. IFN has a short half-life in the circulation and needs frequent administration, thus can produce severe side effects. As a result, PEG-IFN has recently been prescribed more often, with a dosage ranging from 90 to $180 \mu \mathrm{g}$ per week. As for NAs, LAM is an often-used agent, with a common dosage of $100 \mathrm{mg}$ /day, sometimes in combination with another NA, such as ADV, to reduce the possibility of developing drug-resistance. Results from NRCTs show that NAs are effective in improving survival. However, it is difficult to make any recommendation based on these data to guide clinical practice. No definite conclusions could be drawn without creditable evidence from RCTs. International collaborations are needed to conduct large multi-centered RCTs in different populations in order to evaluate the most effective combination and administration of these therapeutic agents.

\section{Conclusions}

\subsection{Summary and Suggestions}

HBV and HCV related HCC cause a huge public health burden, especially in HBV endemic areas. Only a small proportion of HCC patients are eligible for curative treatment, namely surgical resection or OLT. Further, survival after the curative treatment is not optimal. High viral replication rates, viral mutations, and infection-associated inflammation are major factors associated with poor outcomes after surgery. Antiviral treatment is therefore an optimal option to prevent HCC recurrence and improve survival. IFN and NAs are currently the major antiviral agents in use. Use of antiviral agents not only inhibits virus replication and re-activation, but also decreases hepatic inflammation and can facilitate further treatment. IFN and NAs, especially IFN, have been proven to be effective in improving HCC prognosis. However, large multicenter RCTs are necessary to determine the most effective regimen of these antivirals in improving the HCC prognosis after surgery. The complex interactions among viral factors, host immunity, and environmental determinants may influence HCC recurrence and survival. However, the underlying mechanisms of this multi-way network have not yet been fully elucidated. A better understanding of the relationships among these factors can aid in developing advanced treatment strategies and improving the life quality of HCC patients. Future research should focus on the roles of viral factors, inflammation-related signaling molecules, and possible environmental factors on HCC occurrence and the effect of antiviral treatments on HCC - or HCC prognosis-associated viral mutants. A systematic scientific approach should be adopted to direct further studies.

\section{Acknowledgments}

None declared.

\section{Authors' Contribution}

The first 3 authors contribute equally to this work.

\section{Financial Disclosure}

National Natural Scientific Foundation of China (81025015, 91129301 and 30921006$)$.

\section{Funding/Support}

None declared.

\section{References}

1. Jemal A, Bray F, Center MM, Ferlay J, Ward E, Forman D. Global cancer statistics. CA Cancer J Clin. 2011;61(2):69-90.

2. El-Serag HB, Rudolph KL. Hepatocellular carcinoma: epidemiology and molecular carcinogenesis. Gastroenterology. 2007;132(7):2557-76.

3. Mazzaferro V, Regalia E, Doci R, Andreola S, Pulvirenti A, Bozzetti $\mathrm{F}$, et al. Liver transplantation for the treatment of small hepatocellular carcinomas in patients with cirrhosis. $N$ Engl J Med. 1996;334(11):693-9.

4. Llovet JM, Schwartz M, Mazzaferro V. Resection and liver transplantation for hepatocellular carcinoma. Semin Liver Dis 2005;25(2):181-200

5. Imamura $\mathrm{H}$, Matsuyama Y, Tanaka E, Ohkubo T, Hasegawa K, Miyagawa $\mathrm{S}$, et al. Risk factors contributing to early and late phase intrahepatic recurrence of hepatocellular carcinoma after hepatectomy. J Hepatol. 2003;38(2):200-7.

6. Wu JC, Huang YH, Chau GY, Su CW, Lai CR, Lee PC, et al. Risk factors for early and late recurrence in hepatitis B-related hepatocellular carcinoma. J Hepatol. 2009;51(5):890-7.

7. Kim SR, Yang J, Kudo M, Hino O. Recent advances in the management of chronic hepatitis B. Hepat Mon. 2011;11(8):601-11.

8. Hoofnagle JH, Seeff LB. Peginterferon and ribavirin for chronic hepatitis C. NEngl J Med. 2006;355(23):2444-51.

9. Emerit I. Cytogenetic methods for detection of oxidative stress and evaluation of antioxidant therapy in hepatitis $C$ infection. Hepat Mon. 2011;11(6):434-9.

10. Sun HC, Zhang W, Qin LX, Zhang BH, Ye QH, Wang L, et al. Positive serum hepatitis $B$ e antigen is associated with higher risk of early recurrence and poorer survival in patients after curative resection of hepatitis B-related hepatocellular carcinoma. J Hepatol. 2007;47(5):684-90.

11. Hung IF, Poon RT, Lai CL, Fung J, Fan ST, Yuen MF. Recurrence of hepatitis B-related hepatocellular carcinoma is associated with high viral load at the time of resection. Am J Gastroenterol. 2008;103(7):1663-73.

12. Xia F, Lai EC, Lau WY, Ma K, Li X, Bie P, et al. High Serum Hyaluronic Acid and HBV Viral Load are Main Prognostic Factors of Local Recurrence after Complete Radiofrequency Ablation of Hepatitis B-Related Small Hepatocellular Carcinoma. Ann Surg Oncol. 2011.

13. Hosaka T, Suzuki F, Kobayashi M, Hirakawa M, Kawamura Y, Yatsuji $\mathrm{H}$, et al. HBcrAg is a predictor of post-treatment recurrence of hepatocellular carcinoma during antiviral therapy. Liver Int 2010;30(10):1461-70.

14. Yamanaka N, Takada M, Tanaka T, Yamanaka J, Yasui C, Ando T, et al. Viral serostatus and coexisting inflammatory activity affect metachronous carcinogenesis after hepatectomy for hepatocellular carcinoma. A further report. J Gastroenterol. 2000;35(3):20613.

15. Yeh CT, So M, Ng J, Yang HW, Chang ML, Lai MW, et al. Hepatitis $B$ virus-DNA level and basal core promoter A1762T/G1764A mutation in liver tissue independently predict postoperative survival 
in hepatocellular carcinoma. Hepatology. 2010;52(6):1922-33.

16. An HJ, Jang JW, Bae SH, Choi JY, Cho SH, Yoon SK, et al. Sustained low hepatitis B viral load predicts good outcome after curative resection in patients with hepatocellular carcinoma. J Gastroenterol Hepatol. 2010;25(12):1876-82.

17. Tokuhisa Y, Iizuka N, Sakaida I, Moribe T, Fujita N, Miura T, et al. Circulating cell-free DNA as a predictive marker for distant metastasis of hepatitis $\mathrm{C}$ virus-related hepatocellular carcinoma. $\mathrm{Br}$ J Cancer. 2007;97(10):1399-403.

18. Kubo S, Nishiguchi S, Shuto T, Tanaka H, Tsukamoto T, Hirohashi $\mathrm{K}$, et al. Effects of continuous hepatitis with persistent hepatitis C viremia on outcome after resection of hepatocellular carcinoma.Jpn J Cancer Res. 1999;90(2):162-70.

19. Grivennikov SI, Greten FR, Karin M. Immunity, inflammation, and cancer. Cell. 2010;140(6):883-99.

20. Bertuzzo VR, Cescon M, Ravaioli M, Grazi GL, Ercolani G, Del Gaudio M, et al. Analysis of factors affecting recurrence of hepatocellular carcinoma after liver transplantation with a special focus on inflammation markers. Transplantation. 2011;91(11):1279-85.

21. Fu J, Xu D, Liu Z, Shi M, Zhao P, Fu B, et al. Increased regulatory T cells correlate with CD8 T-cell impairment and poor survival in hepatocellular carcinoma patients. Gastroenterology. 2007;132(7):2328-39.

22. Liu L, Zhu XD, Wang WQ, Shen Y, Qin Y, Ren ZG, et al. Activation of beta-catenin by hypoxia in hepatocellular carcinoma contributes to enhanced metastatic potential and poor prognosis. Clin Cancer Res. 2010;16(10):2740-50.

23. Mun HS, Lee SA, Kim H, Hwang ES, Kook YH, Kim BJ. Novel F141L pre-S2 mutation in hepatitis B virus increases the risk of hepatocellular carcinoma in patients with chronic genotype $\mathrm{C}$ infections. J Virol. 2011;85(1):123-32.

24. Han YF, Zhao J, Ma LY, Yin JH, Chang WJ, Zhang HW, et al. Factors predicting occurrence and prognosis of hepatitis-B-virus-related hepatocellular carcinoma. World J Gastroenterol. 2011;17(38):425870.

25. Liu S, Xie J, Yin J, Zhang H, Zhang Q, Pu R, et al. A matched casecontrol study of hepatitis $B$ virus mutations in the preS and core promoter regions associated independently with hepatocellular carcinoma. J Med Virol. 2011;83(1):45-53.

26. Liu S, Zhang H, Gu C, Yin J, He Y, Xie J, et al. Associations between hepatitis B virus mutations and the risk of hepatocellular carcinoma: a meta-analysis. J Natl Cancer Inst. 2009;101(15):1066-82.

27. Yin J, Xie J, Zhang H, Shen Q, Han L, Lu W, et al. Significant association of different pres mutations with hepatitis B-related cirrhosis or hepatocellular carcinoma. J Gastroenterol. 2010;45(10):106371.

28. Cao GW. Clinical relevance and public health significance of hepatitis B virus genomic variations. World J Gastroenterol. 2009;15(46):5761-9.

29. Kay A, Zoulim F. Hepatitis B virus genetic variability and evolution. Virus Res. 2007;127(2):164-76.

30. Tsai HW, Lin YJ, Lin PW, Wu HC, Hsu KH, Yen CJ, et al. A clustered ground-glass hepatocyte pattern represents a new prognostic marker for the recurrence of hepatocellular carcinoma after surgery. Cancer. 2011;117(13):2951-60.

31. Nakamoto S, Imazeki F, Fukai K, Fujiwara K, Arai M, Kanda T, et al. Association between mutations in the core region of hepatitis $C$ virus genotype 1 and hepatocellular carcinoma development. J Hepatol. 2010;52(1):72-8.

32. Toyoda H, Kumada T, Kaneoka Y, Maeda A. Amino acid substitutions in the hepatitis $C$ virus core region are associated with postoperative recurrence and survival of patients with $\mathrm{HCV}$ genotype 1b-associated hepatocellular carcinoma. Ann Surg. 2011;254(2):326-32.

33. Huang L, Li J, Lau WY, Yan J, Zhou F, Liu C, et al. Perioperative reactivation of hepatitis $\mathrm{B}$ virus replication in patients undergoing partial hepatectomy for hepatocellular carcinoma. J Gastroenterol Hepatol. 2012;27(1):158-64.

34. Breitenstein S, Dimitroulis D, Petrowsky H, Puhan MA, Mullhaupt B, Clavien PA. Systematic review and meta-analysis of interferon after curative treatment of hepatocellular carcinoma in patients with viral hepatitis. BrJ Surg. 2009;96(9):975-81.
35. Ikeda K, Arase Y, Saitoh S, Kobayashi M, Suzuki Y, Suzuki F, et al. Interferon beta prevents recurrence of hepatocellular carcinoma after complete resection or ablation of the primary tumor-A prospective randomized study of hepatitis $\mathrm{C}$ virus-related liver cancer. Hepatology. 2000;32(2):228-32.

36. Kubo S, Nishiguchi S, Hirohashi K, Tanaka H, Shuto T, Kinoshita H. Randomized clinical trial of long-term outcome after resection of hepatitis $C$ virus-related hepatocellular carcinoma by postoperative interferon therapy. BrJ Surg. 2002;89(4):418-22.

37. Shiratori Y, Shiina S, Teratani T, Imamura M, Obi S, Sato S, et al. Interferon therapy after tumor ablation improves prognosis in patients with hepatocellular carcinoma associated with hepatitis C virus. Ann Intern Med. 2003;138(4):299-306.

38. Lin SM, Lin CJ, Hsu CW, Tai DI, Sheen IS, Lin DY, et al. Prospective randomized controlled study of interferon-alpha in preventing hepatocellular carcinoma recurrence after medical ablation therapy for primary tumors. Cancer. 2004;100(2):376-82.

39. Sun HC, Tang ZY, Wang L, Qin LX, Ma ZC, Ye QH, et al. Postoperative interferon alpha treatment postponed recurrence and improved overall survival in patients after curative resection of HBV-related hepatocellular carcinoma: a randomized clinical trial.J Cancer Res Clin Oncol. 2006;132(7):458-65.

40. Mazzaferro V, Romito R, Schiavo M, Mariani L, Camerini T, Bhoori $S$, et al. Prevention of hepatocellular carcinoma recurrence with alpha-interferon after liver resection in HCV cirrhosis. Hepatology. 2006;44(6):1543-54.

41. Lo CM, Liu CL, Chan SC, Lam CM, Poon RT, Ng IO, et al. A randomized, controlled trial of postoperative adjuvant interferon therapy after resection of hepatocellular carcinoma. Ann Surg. 2007;245(6):831-42.

42. Singal AG, Volk ML, Jensen D, Di Bisceglie AM, Schoenfeld PS. A sustained viral response is associated with reduced liver-related morbidity and mortality in patients with hepatitis $\mathrm{C}$ virus. Clin Gastroenterol Hepatol. 2010;8(3):280-8, 8 e1.

43. Miao RY, Zhao HT, Yang HY, Mao YL, Lu X, Zhao Y, et al. Postoperative adjuvant antiviral therapy for hepatitis $\mathrm{B} / \mathrm{C}$ virus-related hepatocellular carcinoma: a meta-analysis. World J Gastroenterol. 2010;16(23):2931-42.

44. Suou T, Mitsuda A, Koda M, Matsuda H, Maruyama S, Tanaka H, et al. Interferon alpha inhibits intrahepatic recurrence in hepatocellular carcinoma with chronic hepatitis C: a pilot study. Hepatol Res. 2001;20(3):301-11.

45. Hung $\mathrm{CH}$, Lee CM, Wang JH, Tung HD, Chen CH, Lu SN. Antiviral therapy after non-surgical tumor ablation in patients with hepatocellular carcinoma associated with hepatitis C virus. J Gastroenterol Hepatol. 2005;20(10):1553-9.

46. Sakaguchi Y, Kudo M, Fukunaga T, Minami Y, Chung H, Kawasaki T. Low-dose, long-term, intermittent interferon-alpha-2b therapy after radical treatment by radiofrequency ablation delays clinical recurrence in patients with hepatitis $C$ virus-related hepatocellular carcinoma. Intervirology. 2005;48(1):64-70.

47. Akamatsu M, Yoshida H, Shiina S, Teratani T, Obi S, Tateishi R, et al. Sustained viral response prolonged survival of patients with C-viral hepatocellular carcinoma. Liver Int. 2006;26(5):536-42.

48. Someya T, Ikeda K, Saitoh S, Kobayashi M, Hosaka T, Sezaki H, et al. Interferon lowers tumor recurrence rate after surgical resection or ablation of hepatocellular carcinoma: a pilot study of patients with hepatitis B virus-related cirrhosis. J Gastroenterol. 2006;41(12):1206-13.

49. Kudo M, Sakaguchi Y, Chung H, Hatanaka K, Hagiwara S, Ishikawa $\mathrm{E}$, et al. Long-term interferon maintenance therapy improves survival in patients with HCV-related hepatocellular carcinoma after curative radiofrequency ablation. A matched case-control study. Oncology. 2007;72 (Suppl 1):132-8.

50. Jeong SC, Aikata H, Katamura Y, Azakami T, Kawaoka T, Saneto H, et al. Effects of a 24-week course of interferon-alpha therapy after curative treatment of hepatitis $\mathrm{C}$ virus-associated hepatocellular carcinoma. World J Gastroenterol. 2007;13(40):5343-50.

51. Jeong S, Aikata H, Katamura Y, Azakami T, Kawaoka T, Saneto H, et al. Low-dose intermittent interferon-alpha therapy for HCVrelated liver cirrhosis after curative treatment of hepatocellular carcinoma. World J Gastroenterol. 2007;13(39):5188-95. 
52. Qu LS, Jin F, Huang XW, Shen XZ. Interferon-alpha therapy after curative resection prevents early recurrence and improves survival in patients with hepatitis B virus-related hepatocellular carcinoma. J Surg Oncol. 2010;102(7):796-801.

53. Chan AC, Chok KS, Yuen WK, Chan SC, Poon RT, Lo CM, et al. Impact of antiviral therapy on the survival of patients after major hepatectomy for hepatitis B virus-related hepatocellular carcinoma. Arch Surg. 2011;146(6):675-81.

54. Ishikawa T, Higuchi K, Kubota T, Seki KI, Honma T, Yoshida T, et al. Combination PEG-IFN a-2b/Ribavirin Therapy Following Treatment of Hepatitis C Virus-Associated Hepatocellular Carcinoma is Capable of Improving Hepatic Functional Reserve and Survival. Hepatogastroenterology. 2011;59(115-116).

55. von Marschall Z, Scholz A, Cramer T, Schafer G, Schirner M, Oberg K, et al. Effects of interferon alpha on vascular endothelial growth factor gene transcription and tumor angiogenesis. J Natl Cancer Inst. 2003;95(6):437-48.

56. Wang L, Wu WZ, Sun HC, Wu XF, Qin LX, Liu YK, et al. Mechanism of interferon alpha on inhibition of metastasis and angiogenesis of hepatocellular carcinoma after curative resection in nude mice. J Gastrointest Surg. 2003;7(5):587-94.

57. Wang L, Tang ZY, Qin LX, Wu XF, Sun HC, Xue Q, et al. High-dose and long-term therapy with interferon-alfa inhibits tumor growth and recurrence in nude mice bearing human hepatocellular carcinoma xenografts with high metastatic potential. Hepatology. 2000;32(1):43-8.

58. Keng VW, Tschida BR, Bell JB, Largaespada DA. Modeling hepatitis $B$ virus $X$-induced hepatocellular carcinoma in mice with the Sleeping Beauty transposon system. Hepatology. 2011;53(3):78190.

59. Lee HH, Uen YH, Tian YF, Sun CS, Sheu MJ, Kuo HT, et al. Wnt-1 protein as a prognostic biomarker for hepatitis B-related and hepatitis C-related hepatocellular carcinoma after surgery. Cancer Epidemiol Biomarkers Prev. 2009;18(5):1562-9.

60. Thompson MD, Dar MJ, Monga SP. Pegylated interferon alpha targets Wnt signaling by inducing nuclear export of beta-catenin.J Hepatol. 2011;54(3):506-12.

61. Hwang S, Ahn CS, Song GW, Kim KH, Moon DB, Oh HB, et al. Posttransplantation prophylaxis with primary high-dose hepatitis $B$ immunoglobulin monotherapy and complementary preemptive antiviral add-on. Liver Transpl. 2011;17(4):456-65.

62. Bihl F, Russmann S, Gurtner V, Di Giammarino L, Pizzi-Bosman L, Michel M, et al. Hyperimmune anti-HBs plasma as alternative to commercial immunoglobulins for prevention of HBV recurrence after liver transplantation. BMC Gastroenterol. 2010;10:71.

63. Ahn J, Cohen SM. Prevention of Hepatitis B Recurrence in Liver Transplant Patients Using Oral Antiviral Therapy without LongTerm Hepatitis B Immunoglobulin. Hepat Mon. 2011;11(8):638-45.

64. Pallier C, Castera L, Soulier A, Hezode C, Nordmann P, Dhumeaux $\mathrm{D}$, et al. Dynamics of hepatitis B virus resistance to lamivudine. Virol. 2006;80(2):643-53.

65. Lok AS, McMahon BJ. Chronic hepatitis B. Hepatology. 2007;45(2):507-39.
66. Piao CY, Fujioka S, Iwasaki Y, Fujio K, Kaneyoshi T, Araki Y, et al Lamivudine treatment in patients with HBV-related hepatocellular carcinoma--using an untreated, matched control cohort. Acta Med Okayama. 2005;59(5):217-24.

67. Kuzuya T, Katano Y, Kumada T, Toyoda H, Nakano I, Hirooka Y, et al. Efficacy of antiviral therapy with lamivudine after initial treatment for hepatitis B virus-related hepatocellular carcinoma. J Gastroenterol Hepatol. 2007;22(11):1929-35.

68. Kubo S, Tanaka H, Takemura S, Yamamoto S, Hai S, Ichikawa T, et al. Effects of lamivudine on outcome after liver resection for hepatocellular carcinoma in patients with active replication of hepatitis B virus. Hepatol Res. 2007;37(2):94-100.

69. Yoshida H, Goto E, Sato T, Ohki T, Masuzaki R, Tateishi R, et al Safety and efficacy of lamivudine after radiofrequency ablation in patients with hepatitis B virus-related hepatocellular carcinoma. Hepatol Int. 2008;2(1):89-94.

70. Li N, Lai EC, Shi J, Guo WX, Xue J, Huang B, et al. A comparative study of antiviral therapy after resection of hepatocellular carcinoma in the immune-active phase of hepatitis B virus infection. Ann Surg Oncol. 2010;17(1):179-85.

71. Zimmerman MA, Ghobrial RM, Tong MJ, Hiatt JR, Cameron AM, Busuttil RW. Antiviral prophylaxis and recurrence of hepatocellular carcinoma following liver transplantation in patients with hepatitis B. Transplant Proc. 2007;39(10):3276-80.

72. Ling R, Mutimer D, Ahmed M. Selection of mutations in the hepatitis B virus polymerase during therapy of transplant recipients with lamivudine. Hepatology. 1996;24:711-13.

73. Liaw YF, Chien RN, Yeh CT, Tsai SL, Chu CM. Acute exacerbation and hepatitis B virus clearance after emergence of YMDD motif mutation during lamivudine therapy. Hepatology. 1999;30(2):567-72.

74. Lai CL, Dienstag J, Schiff E, Leung NW, Atkins M, Hunt C, et al Prevalence and clinical correlates of YMDD variants during lamivudine therapy for patients with chronic hepatitis B. Clin Infect Dis. 2003;36(6):687-96.

75. Yeh CT, Chien RN, Chu CM, Liaw YF. Clearance of the original hepatitis B virus YMDD-motif mutants with emergence of distinct lamivudine-resistant mutants during prolonged lamivudine therapy. Hepatology. 2000;31(6):1318-26.

76. Sayan M, Akhan SC, Senturk O. Frequency and Mutation Patterns of Resistance in Patients with Chronic Hepatitis B Infection Treated with Nucleos(t)ide Analogs in Add-On and Switch Strategies. Hepat Mon. 2011;11(10):835-42.

77. Sherman M, Yurdaydin C, Sollano J, Silva M, Liaw YF, Cianciara J, et al. Entecavir for treatment of lamivudine-refractory, HBeAgpositive chronic hepatitis B. Gastroenterology. 2006;130(7):203949.

78. Yang H, Qi X, Das K. In vitro characterization and molecular modeling analysis of a novel adefovir resistance mutation rtN236T in the HBV polymerase. J Hepatol. 2004;40:114.

79. Lai CL, Gane E, Liaw YF, Hsu CW, Thongsawat S, Wang Y, et al. Telbivudine versus lamivudine in patients with chronic hepatitis B. $N$ Engl J Med. 2007;357(25):2576-88.

80. Yeh CT, Chen T, Hsu CW, Chen YC, Lai MW, Liang KH, et al. Emergence of the rtA181T/sW172* mutant increased the risk of hepatoma occurrence in patients with lamivudine-resistant chronic hepatitis B. BMC Cancer. 2011;11:398. 